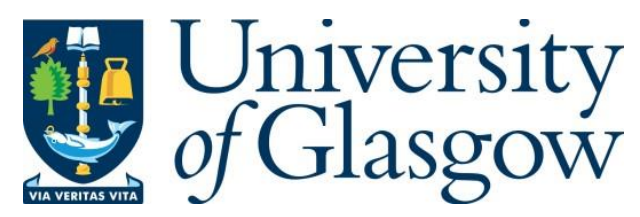

Steel, C. (2017) Re publica nihil desperatius: salvaging the state in Cicero's pre-civil war philosophical works. In: Müller, G. M. and Zini, F. M. (eds.) Philosophie in Rom Römische Philosophie? Kultur-, literatur- und philosophiegeschichtliche Perspektiven. Series: Beiträge zur Altertumskunde (358). De Gruyter, pp. 269-282. ISBN 9783110493108 .

There may be differences between this version and the published version. You are advised to consult the publisher's version if you wish to cite from it.

http://eprints.gla.ac.uk/153358/

Deposited on: 12 December 2017

Enlighten - Research publications by members of the University of Glasgow http://eprints.gla.ac.uk 


\title{
Re publica nihil desperatius: salvaging the state in Cicero's pre-civil war philosophical works
}

\author{
CATHERINE STEEL
}

When Cicero summarised his philosophical output in the second book of De divinatione (div. 2,1-4) written in 44 B.C., he treated all the prose treatises that he had written since his consulship (with the single puzzling exception of de legibus) as a single oeuvre. No distinction is drawn between "philosophy' and 'rhetoric' or between works written before and after the watershed of the Civil War and the period of Cicero's active participation in that conflict. De re publica - which he describes as written when he held gubernacula rei publicae - is included in the list after the trio of De natura deorum, De divinatione itself and the prospective De fato; and, invoking the practice of Aristotle and Theophrastus, his oratorii libri, including De oratore alongside Orator and Brutus, are given at the end of the catalogue. But his claim to have left nullus philosophiae locus unilluminated in Latin should be seen as an early stage in their reception rather than a reliable guide to the process of composition, one which imposed system on a series of works which, during the process of their composition, had not had such a rationale. If the three works written in the fifties B.C., that is De oratore, De re publica and De legibus, are considered as a discrete group, they emerge as products of a very specific and changing political environment, which posed for Cicero a series of challenges about his own achievements, influence and power at the same time as it set up a new and distinctive iteration of the Roman res publica's perennial difficulty with individual power: the individual in question being not Caesar, but Pompeius. Moreover, and despite the strong links between the three works in terms of structure and style, a progression from De oratore to De legibus can be traced, which reflects large albeit ultimately ephemeral changes at Rome in the second half of the $50 \mathrm{~s}$.

The links between Cicero's literary career and his public activity have been extensively investigated in recent years. ${ }^{1}$ One element in this question is

1 John Dugan: Making a New Man. Ciceronian self-fashioning in the rhetorical works, Oxford 2005; Catherine Steel: Reading Cicero. Genre and Performance in Republican Rome, London 2005; Ingo Gildenhard: Creative Eloquence. The construction of reality 
the degree of variation across time. On even the latest dating for Cicero's earliest works, he was active as a writer for nearly four decades, and different kinds of published text are prominent at different moments during this span of time according to the nature of Cicero's public persona and activity. ${ }^{2}$ Prior to his debut as an orator he briefly explored the possibilities of otium, in his poetry, and of theoretical writing, in De inventione; once an advocate, oratory was apparently all-encompassing until he had secured the position of consul, and the record of published works tells a story of increasing engagement with the concerns of the res publica, as civil cases and murder committed by non-senators gives way to the crimes arising from the tenure of imperium, and senatorial clients. ${ }^{3}$ The crisis during Cicero's consulship in 63 sparked an obsessive interest in seizing control of memorialisation, both through the presentation of the speeches he delivered in 63 as a corpus of oratory, and in exploring the possibilities of other genres of writing, poetry as well as prose, and Greek as well as Latin. ${ }^{4}$ The periods during which the two series of treatises were composed - the three works from the 50s and the encyclopaedic collection of rhetorical and philosophical works written between 46 and 44 - were ones when Cicero's political activity was curtailed, and oratory was much less prominent among Cicero's written outputs at those times. The final unexpected political challenge of 44-43 demanded not only a new kind of oratory but a new approach to communication, in which the texts of speeches work alongside letters to create, or so Cicero hoped, a Mediterranean-wide coalition to challenge Antonius. ${ }^{5}$ Letters, indeed, would seem to be the only written form in constant use throughout his career; and yet, whilst we can fairly assume that Cicero did write frequently as a young man to friends and acquaintances, the editorial

in Cicero's speeches, Oxford 2011; Yelena Baraz: A Written Republic. Cicero's political philosophy, Princeton 2012; Sarah Culpepper Stroup: Catullus, Cicero and a society of patrons. The generation of the text, Cambridge 2012.

2 On the composition of De inuentione, see Anthony Corbeill: Rhetorical education in Cicero's youth, in: J. May (ed.): Brill's Companion to Cicero: Oratory and Rhetoric, Leiden 2002, 23-48.

3 Cicero's first senatorial client was Fonteius, whom he defended in 69 B.C. See further Catherine Steel: Cicero's Autobiography. Narratives of Success in the pre-consular orations, in: Cahiers Glotz 23 (2012[2013]), 251-266.

4 Cic. Att. 2,1,3, on his 'consular orations'; other compositions, prospective and actual, recur through book 2 of the letters to Atticus.

5 On the period of the Philippics, Krešimir Matijevic: Marcus Antonius: Consul, Proconsul, Staatsfeind. Die Politik der Jahre 44 und 43 v. Chr, Rahden 2006; Gesine Manuwald: Cicero, Philippics 3-9, 2 vols., Berlin 2007; Jon Hall: Saviour of the republic and Father of the Fatherland: Cicero and political crisis, in: Catherine Steel (ed.): The Cambridge Companion to Cicero, Cambridge 2013, 215-229. 
processes to which the archive was subjected - which, as White has demonstrated, were highly interventionist - created an epistolary Cicero of mature years (nearly 40 when the surviving correspondence begins) and political clout (Att. 1,1 begins the record by framing the question, will Cicero win the consular election?). ${ }^{6}$

Cicero was thus engaged in writing philosophy at two distinct and quite brief periods during a much longer writing career. Between 55 and - perhaps - 51 he planned and, to a large extent drafted, three substantial treatises on what might broadly be termed political theory. Five or so years later, he began a series of treatises which aimed to deal systematically and comprehensively with the topics of philosophy. The two sets of works offer numerous constrasts, despite the attempt of div. 2 to integrate them into a whole. The former claims a special relationship with Plato, though one evident in style and setting rather than detailed content; it uses a dialogue format which subordinates systematic instruction to naturalistic conversation; and is the product of a relatively slow compositional process. ${ }^{7}$ The latter is designedly eclectic in its philosophical allegiances, relentlessly didactic, frequently experimental in format and composed with astonishing speed, which underpins the plausible hypothesis that, in this second phase, Cicero borrowed extensively from the works he consulted, albeit with, at the least, wholesale editorial intervention combined with substantial original composition. ${ }^{8}$

There are also characteristics which both sets share: a concern to place philosophy in a historicised Roman context, an overt relationship with Greek texts and a claim that philosophical composition is a form of public service. Above all, both sets are the products of political environments which were, from Cicero's perspective, deeply unsatisfactory and which led to his disengagement from active public life. However, it is important to recall that the nature of the political crisis was very different in each case. When Cicero

6 Peter White: Cicero in Letters: Epistolary Relations of the Late Republic, Oxford 2010, 31-61.

7 On the links with Plato, Jean Louis Ferrary: L'archéologie du re publica $(2,2,4-37,63)$. Cicéron entre Polybe et Platon, in: Journal of Roman Studies (1984), 87-98; James Zetzel: Plato with pillows: Cicero on the uses of Greek culture, in: David Braund; Christoph Gill (eds.): Myth, History and Culture in Republican Rome, Exeter 2003, 119-138; Jed W. Atkins: Cicero on the relationship between Plato's Republic and Laws, in: Anne Sheppard (ed.): Ancient Approaches to Plato's Republic, London 2013, 15-34; on dialogue, Malcom Schofield: Ciceronian Dialogue, in: Simon Goldhill (ed.): The End of Dialogue in Antiquity, Cambridge 2008, 63-84.

8 On the later series, Ingo Gildenhard: Paideia Romana. Cicero's Tusculan Disputations, Cambridge 2007; Yelena Baraz: Written Rome (as in n. 1); cf. Cic. Att. 12,52,3:

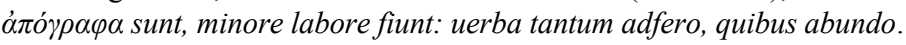


wrote the second series, Rome was an autocracy; Cicero had even resumed some public activity after the period of internal exile at Brundisium, but the speeches he delivered in this period show, through their form, the extent of the transformation in Roman society under Caesar's dictatorship. ${ }^{9}$ In the late $50 \mathrm{~s}$, Cicero was a senior consular engaged in the affairs of the res publica; and though the problem of individual power was also acute at this time, it was a matter of the relationship between individual and the res publica rather than a question of tyranny and the extinction of the res publica. I suggest that the three treatises from this period are animated by a conviction that the state of the res publica is capable of amelioration, a process in which Cicero himself can and should play a key role. Further, this conviction is intimately related to the position and behaviour of Pompeius Magnus, whose place in the res publica shaped the way that Cicero approached the question of personal power and the role of the individual. It is also possible to argue that changes in approach over the course of the three works reflect developments in the political environment at Rome between Pompeius' second and third consulships.

The first definite indication that Cicero was engaged in writing $D e$ oratore is a notice of its completion in a letter to Atticus datable to midNovember 55 (Att. 4,13,2): de libris oratoriis factum est a me diligenter; diu multumque in manibus fuerunt; describas licet. The consuls of this year were Pompeius and Crassus, for the second time; they had won those positions at elections whose manipulation, through violence, went far beyond the normal competitive urges of the Roman elite and relied in part on the votes of Caesar's soldiers, demonstrating that the alliance between the three men, which had appeared to unravel after its immediate ends were served during Caesar's consulship in 59, had been effectively renewed. ${ }^{10}$ Cicero's distaste at the situation as their renewed co-operation became apparent over the

9 Pro Marcello looks ahead to imperial panegyric, however far it may be argued that it struggles with the form of tyrannical praise: see David Levene: God and Man in the Classical Latin Panegyric, in: Proceedings of the Cambridge Philological Society 43 (1997), 66-103; John Dugan: Cicero and the Politics of Ambiguity, in: C. Steel; H. van der Blom (eds.): Community and Communication: Oratory and Politics in Republican Rome, Oxford 2013, 211-225; Pro Ligario and Pro rege Deiotaro mimic the form of Republican oratory while indicating unambiguously that decisions now lie with Caesar: Jeffrey Johnson: The Dilemma of Cicero's Speech for Ligarius, in J. Powell; J. Paterson (eds.): Cicero the Advocate, Oxford 2004, 371-399; Andrew Lintott: Cicero as Evidence, Oxford 2008, 317-321, 335-337.

10 Fergus Millar: The Crowd in Rome in the Late Republic, Ann Arbor 1998, 164-166; Alexander Yakobson: Elections and Electioneering in Rome. A study of the political system of the late Republic, Stuttgart 1999, 160-171; Robin Seager: Pompey the Great, $2^{\text {nd }}$ ed., London 2002, 120-122. 
summer of 56 can be seen in letters to Atticus and Quintus. ${ }^{11}$ His decision to write a large-scale prose work in a form other than a speech can be linked to these political developments which he found so troubling.

Nonetheless, the year 55 was not the first moment that Cicero responded to what he perceived as a transformation of the res publica for the worse by contemplating a turn to new literary forms. In 59, extensive surviving correspondence with Atticus, beginning in April 59 (Att. 2,4-2,17) shows Cicero responding to the nature of Caesar's first consulship by considering withdrawal from active political engagement. By the time that Cicero had left Rome for the spring break, and thus resumed the correspondence with Atticus (Att. 2,4) his attitude had shifted from the earnest reflection of Att. 2,3, from December 60, in which he considers his options for Caesar's consulship - framing his argument in explicitly Socratic terms - before concluding that he must continue his opposition to Caesar and his allies. In Att. 2,4 gloom about the res publica is combined with plans to engage in a substantial piece of literary composition: Cicero claims that he has decided statui $[\ldots]$ nihil iam de re publica cogitare. Withdrawal and study continue to be the dominant aspects of this sequence of, even in the face of news of Pompeius' ever closer rapprochement with Caesar, leading Cicero to con-

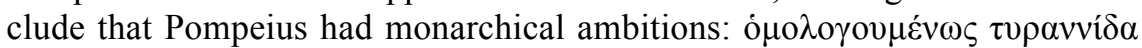
$\sigma v \sigma \kappa \varepsilon v \alpha \dot{\zeta} \varepsilon \tau \alpha l(2,17,1)$. The great work that Cicero was planning at this point was one on geography; he had already written a prose account of his consulship, but this work would have been the first time that he turned to a theoretical prose work, which did not directly record his own activities, for over two decades. It would have been a new departure and it seems reasonable to link the decision to what seemed to be a changed political world.

The final part of the second book of letters to Atticus $(2,18-2,25)$ were written between June and August or September 59, when Cicero had returned to Rome and Atticus departed for Greece. The analysis of political events in these letters is not entirely coherent, but at least two elements can be identified which contributed to Cicero's conclusion that the situation was bad, and likely to become worse. One is the novelty of Caesar's power, and the threat «that it therefore poses to the freedom of private individuals and even of other magistrates».12 The second is the universal hostility felt

11 Cic. Att. 4,5,1-3; 4,8a,2; Cic. Q. fr. 2,9,3. His response to events during 55 itself is much more difficult to gauge, as he and Atticus were both in Rome for much of the year (the exception being in the late spring, when Cicero, as often left Rome during the holiday around the feriae Latinae) as was his brother Quintus, who had returned from Sardinia in June 56 (Q. fr. 2,8 seems to have been prompted by a short trip from Rome on Quintus' part).

12 Cic. Att. 2,18,1-2; 2,20,3. 
towards Pompeius and Caesar. ${ }^{13}$ Although Cicero does not talk explicitly about war in these letters, it is clear that observations such as haec quo sint eruptura timeo (Att. 2,20,3) and sed certe uidentur haec aliquo eruptura (Att. 2,22,5) reflect an anxiety that intense political factionalism will turn into violent conflict - as had happened in 88 and again in 87, when Cicero was an adolescent in Rome. Thus the letters combine a belief that the unrestrained power of Caesar was itself the problem, and a fear that power will provoke some form of resistance. The problem is one of consensus: the res publica is in danger because the mechanisms which ensure that it does genuinely involve all its members - all genera, ordines and aetates, as Cicero puts it in Att. 2,19,2 - are under threat. To this extent, Cicero's perception of the situation during Caesar's consulship is slightly different from his earlier anxieties in the period after his consulship. He did react to Clodius' acquittal in 61 with the observation that rei publicae statum illum [...] elapsum scito esse de manibus (Att. 1,16,6), but even in same letter Cicero congratulates himself on his success in rallying the boni. At the end of that year, after a long hiatus in the correspondence with Atticus, he describes the res publica as infirma, misera commutabilique (Att. 1,17,8) whilst writing at length about the details of the political environment and his own contribution thereto. The res publica was under threat: but action was still worthwhile, in contrast the emphasis on withdrawal evident in the letters from 59.

Cicero, however, never completed his work on geography that he was planning in 59; indeed, there is little evidence that he made much progress at all. There may have been aspects of the project itself which turned out to be unappealing: but there were also differences between the crises of 59 and of $56-55$, not least in terms of Cicero's own involvement. He was sidelined in 59, but so was everybody else except Caesar, Pompeius and their immediate allies. In 56, general chaos was supplemented by personal failure. The eightmonth period which followed Cicero's return from exile in September 57 was one in which Cicero was, to a very great extent, able to demonstrate his auctoritas. He overturned Clodius' dedication of the site of his house; he successfully resumed his role as an advocate, with no fewer than four attested acquittals in the first four months of 56 (Asicius, Calpurnius Bestia, Sestius and Caelius); and he played an active role in senatorial debate, including challenging Clodius (particularly over the events which he recorded in the speech De haruspicum responsis) and Caesar over land legislation. Cicero was not exactly 'independent', whatever that might mean in republican Rome, since he had declared close allegiance to Pompeius immediately on his return through his support for the special command on the corn 
supply, and took no action which was demonstrably against Pompeius' interests during this period (Pompeius' interests over the Egyptian question were notoriously difficult to discern) ${ }^{14}$ In fact, to a greater extent than ever before or after, Cicero was living out in these months his ideal of harmonious co-operation with Pompeius whilst fulfilling the role of a senior consular.

This happy state ended abruptly after the spring break of 56, during which Pompeius and Caesar mended their relationship; and Pompeius then instructed Cicero's brother Quintus to inform Cicero that henceforward he needed to moderate his behaviour to accord with the wishes of Caesar as well as Pompeius' own wishes. It is quite clear from Cicero's descriptions of what happened that this was, and was perceived as, a major shift in his position. To Atticus, in June 56, he describes his recantation as subturpicula and bids farewell to sed ualeant recta uera honesta consilia. In the long apologia to Spinther from 54 (Fam. 1,9), Cicero offered, in response to Spinther's query as to how he could possibly have spoken for Vatinius, a narrative of events since his return from exile, in which Pompeius' request to Quintus provoked in Cicero fundamental reflection on his conduct (Fam. 1,9,10):

haec cum ad me frater pertulisset et cum tamen Pompeius ad me cum mandatis Vibullium misisset ut integrum mihi de causa Campana ad suum reditum reseruarem, conlegi ipse me et cum ipsa quasi re publica conlocutus sum.

The letter as a whole is written with extraordinary care, alert to the position of letters as mediators of status and obligation, and such networks provide for Cicero a major determinant of what he should do: his allegiance to Pompeius is based on a relationship dating back to adulescentia; his developing relationship with Caesar assisted by their uetus amicitia and Caesar's known commitment to cultured behaviour. ${ }^{15}$ But Cicero also provides a theoretical and philosophical structure which supports this appeal to personal links. Particularly striking is the quasi-prosopopoeia of the res publica as a dialogue partner for Cicero as he reflected, in the spring of 56 , on what he

14 On the political environment of this period, Anthony Corbeill: The function of a divinely inspired text in Cicero's De Haruspicum Responsis, in: D. Berry; A. Erskine (eds.): Form and Function in Roman Oratory, Cambridge 2010, 139-154; Mary Beard: Cicero's 'Response of the Haruspices' and the Voice of the Gods, in: Journal of Roman Studies 102 (2012), 20-39.

15 On Fam. 1,9, Werner Schneider: Vom Handeln der Römer: Kommunikation und Interaktion der politischen Führungsschicht vor Ausbruch des Bürgerkriegs im Briefwechsel mit Cicero, Hildesheim 1998, 238-318; Jean E. Bernard: Du discours à l'épistolaire: les échos du «Pro Plancio» dans la lettre de Cicéron à Lentulus Spinther (Fam. 1,9), in: Rhetorica 25,3 (2007), 223-242. 
was to do. He also appeals to Plato's guidance, referring both to his observation that citizens resemble their leaders, and to his comment that civic struggle should be limited to words; violence should not be used in familial or state contexts.

The existence and characteristics of De oratore are advertised in some detail towards the close of the letter (Fam. 1,9,23):

scripsi etiam (nam me iam ab orationibus diiungo fere referoque ad mansuetiores Musas, quae me maxime sicut iam a prima adulescentia delectarunt) - scripsi igitur Aristotelio more, quem ad modum quidem uolui, tris libros in disputatione ac dialogo 'de oratore', quos arbitror Lentulo tuo fore non inutilis; abhorrent enim a communibus praeceptis atque omnem antiquorum, et Aristoteliam et Isocratiam, rationem oratoriam complectuntur.

Its presence is far from accidental: one way of reading Fam 1,9 is as a practical appendage to De oratore, which shows how the orator deals with actual political crisis. Part of the problem that Cicero faced in 56 and 55 was that - unlike Caesar's terrifying grip on power in 59 - the political landscape was very variegated. Caesar, Pompeius and Crassus ensured their election as consuls for 55 and managed to keep M. Cato out of the praetorship for that year, but in 55 two of the tribunes of the plebs were hostile to the consuls, if ineffectual, Cato as a priuatus opposed their activities, forcing a violent response, and their opponents were elected to the consulship for $54 .{ }^{16}$ Cicero's political stance of aligning himself with Pompeius and Caesar was thus very obviously a choice among a number of possible lines of action. His reconciliation with Vatinius came early in the year (he had opposed his candidacy for the praetorship, but once Vatinius was elected he dropped his hostility) and, apart from his defence of Caninius Gallus in the autumn, Cicero's main public occupation during 55 was responding to the attacks he faced from Piso Caesoninus. Piso was surely delighted to find on his return from his province of Macedonia that Cicero was so vulnerable, and the in Pisonem suggests that he seized the opportunity adroitly to dismiss Cicero's manouevrings against him as the futile efforts of a deluded lackey.

Cicero's decision to write a substantial prose work on oratory thus took place in an environment that was much more personally challenging than is often acknowledged. The nature of De oratore's achievement has been emphasised in recent work: its scale, its ambition, the confidence with which it reshapes Greek models into a distinctively Roman creation, and the skill with which technical rhetorical instruction is combined with a discursive account

16 The tribunes Aquillius Gallus and Ateius Capito attempted to block the passage of the lex Trebonia; Domitius Ahenobarbus and Appius Claudius were elected to the consulship of 54, the former bitterly opposed to Pompeius and Caesar. 
of public speech at Rome. ${ }^{17}$ These claims are undeniable, but do not override more local concerns. The preface's description of a crisis for the res publica which poses for Cicero the dilemma of participation versus otium smacks of special pleading, insofar as Cicero's claims to be occupied in saving the state, during the second consulship of Pompeius and Crassus, might seem to many readers implausible. More importantly, De oratore is a profoundly inconclusive work, which refuses to provide answers to the questions it poses and at times leaves its characters in explicit uncertainty. ${ }^{18}$ Cicero's demonstration, through the adoption of dialogue format, that the conduct of individuals within the Roman res publica was a matter about which, like the topics of Greek philosophical dispute, firm conclusions may not be reachable is a more surprising move than we, habituated to dialogue as a medium for philosophy at Rome largely through Cicero's own writings, tend to grasp. The philosophical consequences have been well discussed elsewhere; but the practical implication also needs to be emphasised. De oratore shows how political disagreement can take place and be managed. In the context of 55, when political disagreement was turning into lethal violence, that was a message with urgent resonance. And insofar as De oratore suggests there may be a solution, it appears to be persuasive speech - oratory. It is nonetheless frustratingly hard to identify further necessary conditions which $D e$ oratore establishes for controlled disagreement. The participants in De orato$r e$ 's dialogue knew one another intimately; many were related to each other; they shared an educational background; and they were all participants in the res publica, as magistrates, ex-magistrates, advocates and - in the case of four of the seven participants - priests. They do not, that is, provide a test case for the capacity of speech to manage disagreements among a diverse group. Perhaps the dialogue's location among the fundamentally like-minded points to what was, elsewhere, Cicero's response to intractable civil disagreement, namely the forcible elimination of some individuals from the res publi$c a$ on the grounds that their conduct had turned them into non-citizens. ${ }^{19}$ Do the strong links which already existed between the participants in De oratore undermine its credibility as a demonstration of the capacity of persuasive speech to mediate difference? The presence of Sulpicius among the interlo-

17 Erik Gunderson: Staging Masculinity. The rhetoric of performance in the Roman World, Ann Arbor 2000, 187-222; Elaine Fantham: Roman World of Cicero's De orator, Oxford 2006; John Dugan: Making a New Man (as in n. 1), 75-171; Matthew Fox: Cicero's Philosophy of History, Oxford 2007, 111-141; Joy Connolly: The State of Speech. Rhetoric and political thought in ancient Rome, Princeton 2007, 96-157.

18 Cic. De orat. 1,262.

19 Jill Harries: Cicero and the Jurists. From Citizens' Law to the Lawful State, London 2006, 185-229. 
cutors, who would, less than three years later, institute a crisis (and abandon an exemplary friendship) during his tribunate perhaps signals the limits of civilised discourse, as does the impending disaster which hangs over this gathering in September 91, namely the political crisis which had already led to the breakdown of trust between the consul Philippus and the Senate (with Crassus taking a lead in the latter's opposition to the consul) and which would soon contribute to the outbreak of war between Rome and its Italian allies. $^{20}$

Another area to which the date of composition is directly relevant is the relationship between De oratore's reflections on political leadership and the position and activity of Pompeius. It is tempting to read De oratore as a reflection on Cicero's own career, in which Crassus' exceptionally demanding recipe for the orator matches the range of skills which Cicero had shown over the years, and in which the concluding invocation of Hortensius as the future of Roman oratory silently points to Cicero, who surpassed him. But such a reading risks making Crassus' the dominant voice; Antonius began his contribution in book one by challenging the identification that Crassus has made between orator and statesman (de orat. 1,209-215). For Antonius, an orator is simply someone who can speak competently in forensic cases; public life requires speech, but it does not require eloquence (de orat. 1,213-215):

[...] atque eum puto esse, qui et uerbis ad audiendum iucundis et sententiis ad probandum accommodatis uti possit in causis forensibus atque communibus: hunc appello oratorem [...] neque uero, si quis utrumque potest, aut ille consili publici auctor ac senator bonus ob eam ipsam causam orator est aut hic disertus atque eloquens, si est idem in procuratione ciuitatis egregius, illam scientiam dicendi copia est consecutus: multum inter se distant istae facultates longeque sunt diuersae atque seiunctae $[\ldots]$.

If a reader were to take seriously both definitions, then it would become difficult to ignore Pompeius. He was the dominant figure at Rome; and, as such, when in Rome, a frequent communicator with people and Senate. ${ }^{21} \mathrm{He}$ also had some forensic experience, and seems to have been a more than competent speaker: but the nature of his skill is less important here than the possibility that speech might matter as an aspect of his power. He was arguably not an orator on an Antonian definition, but he clearly was involved in procuratione ciuitatis: what kind of speech was required of such a man in order to maintain the res publica? The Roman elite constantly faced

20 Cicero refers to the political crisis at de orat. 1,24 and 3,2. On Sulpicius, Jonathan Powell: The Tribune Sulpicius, in: Historia 39 (1990), 446-460.

21 Van der Blom: Pompey in the contio, in: Classical Quarterly 61 (2011), 553-573. 
the problem of containing outstanding individuals; even if the precise dynamics of the Pompeius problem were the product of Sulla's constitutional change the broader issue was long-standing. De oratore suggests that any answer must tackle how the elite speak within civil society and that a Pompeius willing to engage with his peers through speech is a Pompeius who can operate within the res publica.

Pompeius is even more apparent in De re publica: not only is that work more explicitly concerned with the nature of political leadership, its setting also leads reflections towards Pompeius. No one individual was dominant in 91 in a manner comparable to Pompeius' position between 55 and 52, but Scipio Aemilianus in 129 did offer a parallel. Moreover, De re publica puts Scipio alongside Laelius and emphasises their friendship (rep. 1,18). Cicero had used the friendship between Scipio and Laelius in 62 as an analogy for the relationship he wanted to have with Pompeius in the only surviving letter to from Cicero to him (Fam. 5,7). ${ }^{22}$ Further parallels between the two men can be drawn: excellence in military leadership, a record of being summoned by the people to solve intractable problems, association with intellectuals and perhaps even liability to assassination. If the argument is accepted that rector rei publicae is simply Cicero's phrase for what we might call a 'statesman', then the idea that one purpose of De re publica is to grapple with Pompeius' status becomes even more compelling. ${ }^{23}$ By the time Cicero started working on De re publica in the spring of 54, Pompeius' position had arguably become even stronger than it had been during his second consulship; through the lex Trebonia he held five years' imperium but - entirely without precedent - was running his province through legates whilst remaining himself near Rome and intervening in political life at Rome, with Senate meetings held outside the pomerium in order to accommodate his attendance. This was a new kind of power; what were its implications? Was Rome's mixed constitution sufficiently robust to incorporate this new development in its long history of constitutional development? Cicero had reflected in detail on the nature of Pompeius' extraordinary power as early as 66, when he delivered his speech De imperio Cn. Pompei, in support of the proposal to give Pompeius the command against Mithridates, and created a magnetic description of Pompeius as the ideal Roman general who combined skill, courage and divine favour with a spotless probity. It is attractive to see in De re publica a

22 Jean E. Bernard: La Socialité épistolaire chez Cicéron, Paris 2013, 268-281.

23 Jonathan Powell: The rector rei publicae of Cicero's De re publica, in: Scripta Classica Israelica 13 (1994), 19-29; more generally, Malcolm Schofield: Saving the City. Philosopher-Kings and other Classical Paradigms, London 1999, 178-194. 
veiled return to exhortation directed at Pompeius, though now his responsibilities are to the res publica as a whole. ${ }^{24}$

The date at which the text of De re publica was finalised is unclear, but if it was finished during 53 it very soon received optimistic endorsement in the events of 52, when Pompeius, as sole consul, effected an extraordinary, though short-lived political transformation that seemed to cure the problem of political violence and re-establish orderly government. ${ }^{25}$ For Cicero, even as civil war threatened, it was illo diuino tertio consulatu (Att. 7,1,4). Diuinus is significant: Pompeius had, however briefly, assumed the status of one who would receive the reward described by Scipio at the end of book 6 of De re publica. The effects of Pompeius' third consulship may also be visible in De legibus, though its composition history is a notorious problem. Its contemporary setting, as a dialogue between Cicero, Quintus Cicero and Atticus, permits reference to Pompeius and each of the dialogue's characters praise his actions; their words are not so precise as to clarify dating, though sufficiently warm as to suggest that they may be directly influenced by the consulship of 52. 'Atticus' notes (De leg. 1,8) that if Cicero were to write contemporary history he could praise Pompeius; his restoration of the tribunes' powers in 70 is the sole flaw in his otherwise splendid career for 'Quintus' $(3,22)$, and this act is then defended by 'Marcus' $(3,26)$. More speculatively, it is possible that the tranquillity of Rome after the conviction of Milo and the election of Scipio Nasica as Pompeius' consular colleague might have contributed to broader issues in the composition and tone of $D e$ legibus. It does not portend imminent crisis, as the two earlier works do; and it has a contemporary setting - perhaps because where there is less wrong, there is less potential to cause offence? Whilst the work continues to demonstrate the potential of dialogue form to accommodate difference, it offers much more emphatic direction through 'Marcus" exposition of an ideal law code, whose basic validity is not questioned by 'Atticus' or 'Quintus'. It is a more optimistic work about the Roman res publica and its capacity to serve the interests of its citizens in more or less its current form. The difficulty with such an interpretation is that it would force the date of composition well into the second half of 52, since it would imply that Pompeius'

24 That is, De re publica and De imperio Cn. Pompei can be read as the earliest Roman examples of the 'mirror for princes' genre, to which Cicero's Pro Marcello is more commonly seen as a contribution, and which emerges clearly in the writings of the younger Seneca: Susanna Braund: Praise and Protreptic in early imperial panegyric, in: M. Whitby, ed: The Propaganda of Power: the role of panegyric in Late Antiquity, Leiden 1998, 53-76. I am grateful to Carlos Lévy for his observations on this point.

25 Robin Seager: Pompey the Great (as in n. 10), 133-151. 
third consulship affected the whole tendency of De legibus and did not result only in a small number of complimentary observations.

Cicero's turn to philosophy in the 50s reflected a very different environment from that in which he was writing the series of works composed between 46 and 44 . This earlier series begins at the time of - and perhaps is even initiated by - the public demonstration of Cicero's weakness and dependence on Pompeius in late spring of 56, a weakness that remained until the outbreak of civil war. These treatises attempt to enhance Cicero's auctoritas through their novelty and seriousness as well as to make a claim about the significance of eloquent public speech which is far from borne out by his actual practice as an orator between 57 and 51. In addition, the most immediate challenge to the stability of the res publica was not Caesar, absent in Gaul, but Pompeius. He, as well as Cicero, should be read against the remedies which Cicero reflects on in these treatises, and his success in 52 provides a possible context for the greater confidence and optimism which is discernible in De legibus. As events turned out, a Pompeian rector rei publicae proved a dead end in Cicero's political theory: when he resumed philosophical composition, it was in a political environment now transformed into autocracy. 